\title{
Optimization of selective breeding through analysis of morphological traits in Chinese sea bass (Lateolabrax maculatus)
}

\author{
W. Wang, C.Y. Ma, W. Chen, H.Y. Ma, H. Zhang, Y.Y. Meng, Y. Ni and \\ L.B. Ma
}

Key Laboratory of East China Sea and Oceanic Fishery Resources Exploitation, Ministry of Agriculture, East China Sea Fisheries Research Institute, Chinese Academy of Fishery Sciences, Shanghai, China

Corresponding author: L.B. Ma

E-mail: malingbo@vip.sina.com

Genet. Mol. Res. 15 (3): gmr.15038285

Received December 16, 2015

Accepted February 26, 2016

Published August 18, 2016

DOI http://dx.doi.org/10.4238/gmr.15038285

Copyright $(2016$ The Authors. This is an open-access article distributed under the terms of the Creative Commons Attribution ShareAlike (CC BY-SA) 4.0 License.

\begin{abstract}
Determining correlations between certain traits of economic importance constitutes an essential component of selective activities. In this study, our aim was to provide effective indicators for breeding programs of Lateolabrax maculatus, an important aquaculture species in China. We analyzed correlations between 20 morphometric traits and body weight, using correlation and path analyses. The results indicated that the correlations among all 21 traits were highly significant, with the highest correlation coefficient identified between total length and body weight. The path analysis indicated that total length $\left(\mathrm{X}_{1}\right)$, body width $\left(\mathrm{X}_{5}\right)$, distance from first dorsal fin origin to anal fin origin $\left(\mathrm{X}_{10}\right)$, snout length $\left(\mathrm{X}_{16}\right)$, eye diameter $\left(\mathrm{X}_{17}\right)$, eye cross $\left(\mathrm{X}_{18}\right)$, and slanting distance from snout tip to first dorsal fin origin $\left(\mathrm{X}_{19}\right)$ significantly affected body weight $(\mathrm{Y})$ directly. The following multiple-
\end{abstract}


regression equation was obtained using stepwise multiple-regression analysis: $\mathrm{Y}=-472.108+1.065 \mathrm{X}_{1}+7.728 \mathrm{X}_{5}+1.973 \mathrm{X}_{10}-7.024 \mathrm{X}_{16}-$ $4.400 \mathrm{X}_{17}-3.338 \mathrm{X}_{18}+2.138 \mathrm{X}_{19}$, with an adjusted multiple-correlation coefficient of 0.947 . Body width had the largest determinant coefficient, as well as the highest positive direct correlation with body weight. At the same time, high indirect effects with six other morphometric traits on L. maculatus body weight, through body width, were identified. Hence, body width could be a key factor that efficiently indicates significant effects on body weight in L. maculatus.

Key words: Lateolabrax maculatus; Correlation analysis; Path analysis; Morphological traits; Body weight

\section{INTRODUCTION}

In many aquaculture-breeding programs, body weight is widely used as a direct indicator for selection and is considered an important economic factor for enhancing production. Given the fact that body weight of farmed species has been found to be highly correlated with various morphological traits (Pérez-Rostro and Ibarra, 2003; Trong et al., 2013), many statistical methods had been employed to develop a selection index. This has been done by exploring the relationships among particular morphological traits and estimating the contribution of each morphological trait on the trait of interest, in this case body weight. These methods include correlation analysis, path analysis, and regression analysis. To date, studies of phenotypic and genetic relationships among growth-related traits have been performed in many fish species, including Oncorhynchus mykiss (Kause et al., 2002), Scophthalmus maximus (Wang et al., 2010), Pangasianodon hypophthalmus (Sang et al., 2009), Paralichthys olivaceus (Tian et al., 2011), Penaeus vannamei (Pérez-Rostro and Ibarra, 2003), and Salmo salar (Haffray et al., 2012). For example, nine morphological traits (total length, head length, snout length, body width, head width, interorbital distance, body depth, head depth, and body weight) from juvenile Polyodon spathula were measured, among which total length was the most predominant variable to affect body weight (Yuan et al., 2012). Likewise, in Micropterus salmoides, nine morphometric traits (total length, standard length, body depth, body width, interorbital distance, head length, snout length, caudal peduncle length, and caudal peduncle depth) were analyzed, among these body width had the biggest impact on body weight (He et al., 2009). Because measurement of these traits, such as total length or body width, is considerably easier and faster to perform under field conditions than direct measurement of body weight (Harrison, 2001), these traits could be used in selection studies of aquatic organisms in breeding programs (Zhao et al., 2014).

Chinese sea bass, Lateolabrax maculatus, is a redescribed species (Yokogawa and Seki, 1995; Kim et al., 2001) that was recently distinguished from the Japanese sea bass, L. japonicus. It is widely distributed along the Chinese coast, reaching the borders with Vietnam and Korea (Yokogawa and Seki, 1995; Shao et al., 2009). Its high nutritional value has made it an important commercial species in China. Due to increasing market demands for L. maculatus, cage and pond-culturing of this species have been developed and have spread quickly in the east coast regions of China. However, recently, the amount of resources spent and germplasm degeneration are becoming bottleneck problems that limit further aquaculture

Genetics and Molecular Research 15 (3): gmr.15038285 
development of L. maculatus. To improve aquaculture production of L. maculatus, a number of studies have been carried out investigating growth, feeding, and population structure in this species (Lee and Yang, 2002; Liu et al., 2006; Li et al., 2012; An et al., 2013, 2014; Wang et al., 2015a,b). Although the selection and rearing of breeders with high-productive properties are important tools to improve progeny quality in fish farming (Borrell et al., 2007), efficient breeding programs are currently lacking for L. maculatus.

In the present study, our aim was to understand the relationships among morphological traits, and to identify effective indicators that could be applied in selective breeding programs of L. maculatus. We used correlation and path analyses, to analyze the correlations between body weight and various morphometric traits. Furthermore, regression analysis was performed to construct a best-fit multiple-regression equation. These results could provide useful information that may be used to promote the selection activities in this species.

\section{MATERIAL AND METHODS}

\section{Ethics statement}

The frozen wild L. maculatus samples were collected from the southeast coastal area of China. Due to the scientific research purpose, no permissions were required for this species and sampling area. The sampling locations were not protected or privately owned, and the field sampling did not involve protected or endangered species.

\section{Experimental animal sampling}

A total of 87 wild individuals of $L$. maculatus were collected from three locations in the southeast coastal area of China, Qingdao $(\mathrm{N}=42)$, Dongtou $(\mathrm{N}=23)$, and Lieyu $(\mathrm{N}=22)$, from March 2015 to September 2015. The body integrity of all frozen samples was investigated to ensure the measurement accuracy of all morpholometric traits and body weight.

\section{Measurement of morphological traits}

In total, 21 morphological traits were measured (shown in Figure 1). These included total length $\left(\mathrm{X}_{1}\right)$, body length $\left(\mathrm{X}_{2}\right)$, distance from the tip of lower jaw to anus $\left(\mathrm{X}_{3}\right)$, body height $\left(\mathrm{X}_{4}\right)$, body width $\left(\mathrm{X}_{5}\right)$, caudal peduncle height $\left(\mathrm{X}_{6}\right)$, caudal peduncle length $\left(\mathrm{X}_{7}\right)$, distance from snout tip to first dorsal fin origin $\left(X_{8}\right)$, basal length of dorsal fin $\left(X_{9}\right)$, distance from first dorsal fin origin to anal fin origin $\left(\mathrm{X}_{10}\right)$, distance from the tip of lower jaw to pelvic fin origin $\left(\mathrm{X}_{11}\right)$, basal length of anal fin $\left(\mathrm{X}_{12}\right)$, pectoral fin length $\left(\mathrm{X}_{13}\right)$, pelvic fin length $\left(X_{14}\right)$, head length $\left(X_{15}\right)$, snout length $\left(X_{16}\right)$, eye diameter $\left(X_{17}\right)$, eye cross $\left(X_{18}\right)$, slanting distance from snout tip to first dorsal fin origin $\left(\mathrm{X}_{19}\right)$, distance from the tip of lower jaw to pectoral fin origin $\left(\mathrm{X}_{20}\right)$, and body weight $(\mathrm{Y})$. The first 20 morphometric traits $\left(\mathrm{X}_{1-20}\right)$ were measured to cover most of the phenotypic characters of L. maculatus and to identify any differences among sampled individuals, as described by previous researchers (Harrison, 2001; Ruiz-Campos et al., 2003; Li et al., 2006; He et al., 2009; Liu et al., 2011). The measurements were performed using vernier calipers (accuracy: $0.02 \mathrm{~mm}$ ) to the nearest $0.10 \mathrm{~mm}$ as illustrated in Figure 1.

Genetics and Molecular Research 15 (3): gmr.15038285 


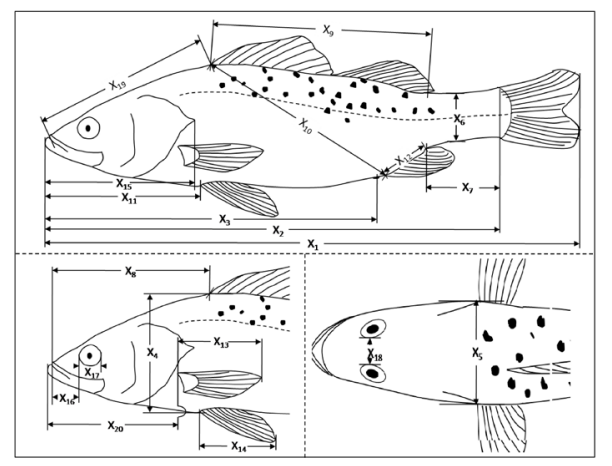

Figure 1. Measurement of the various morphological traits of Lateolabrax maculatus. $\mathrm{X}_{1}=$ total length; $\mathrm{X}_{2}=$ body length; $\mathrm{X}_{3}=$ distance from the tip of lower jaw to anus; $\mathrm{X}_{4}=$ body height; $\mathrm{X}_{5}=$ body width; $\mathrm{X}_{6}=$ caudal peduncle height; $X_{7}=$ caudal peduncle length; $X_{8}=$ distance from snout tip to first dorsal fin origin; $X_{9}=$ basal length of dorsal fin; $X_{10}=$ distance from first dorsal fin origin to anal fin origin; $X_{11}=$ distance from the tip of lower jaw to pelvic fin origin; $X_{12}=$ basal length of anal fin; $X_{13}=$ pectoral fin length; $X_{14}=$ pelvic fin length; $X_{15}=$ head length; $X_{16}=$ snout length; $X_{17}=$ eye diameter; $X_{18}=$ eye cross; $X_{19}=$ slanting distance from snout tip to first dorsal fin origin; $\mathrm{X}_{20}=$ distance from the tip of lower jaw to pectoral fin origin.

The body weight of $L$. maculatus was measured to the nearest $0.01 \mathrm{~g}$ with a digital electronic balance. As shown by a Kolmogorov-Smirnov test, the body weights of all 87 individuals conformed to the law of normal distribution, suggesting that there were no significant differences in body weight among the individuals from different sampling locations. Hence, the collected samples could be used in the following analysis as described by Du and Chen (2010). Because not all sampled individuals had reached sexual maturity, gender was not included in the subsequent analyses.

\section{Data analysis}

The mean value and standard deviation (SD) of all traits were calculated using SPSS 16.0. The coefficient of variation (CV) for each of the 20 recorded morphometric traits and body weight were estimated using the following formula:

$$
\mathrm{CV}=(\mathrm{SD} / \text { mean }) \times 100 \%
$$

(Equation 1)

The path analysis was carried out using SPSS 16.0, as described by Du and Chen (2010). The bivariate correlations among all morphological traits were then determined. A stepwise multiple regression analysis was used to identify which parameters significantly contributed to body weight. Parameters with $\mathrm{P}<0.01$ were subsequently included in the regression analysis as independent variables (Wada, 1986).

The multiple regression equation for body weight (Y) was calculated as follows:

$$
\mathrm{Y}=\mathrm{a}+\mathrm{b}_{1} \mathrm{X}_{1}+\mathrm{b}_{2} \mathrm{X}_{2}+\mathrm{b}_{3} \mathrm{X}_{3}+\ldots+\mathrm{b}_{\mathrm{i}} \mathrm{X}_{\mathrm{i}}
$$

where $Y$ is the dependent variable, $a$ is the intercept, $X_{i}$ are the independent variables, and $b_{i}$ are the partial regression coefficients for $\mathrm{X}_{\mathrm{i}}$ on $\mathrm{Y}$. The determination $\left(\mathrm{d}_{\mathrm{i}}\right)$ and co-determinant $\left(\mathrm{d}_{\mathrm{ij}}\right)$ coefficients were calculated using the following formulae (described by Ma et al., 2013):

Genetics and Molecular Research 15 (3): gmr.15038285 


$$
\begin{gathered}
\mathrm{d}_{\mathrm{i}}=\left(\mathrm{P}_{\mathrm{Y} . \mathrm{Xi}}\right)^{2} \\
\mathrm{~d}_{\mathrm{ij}}=2 \mathrm{Xr}_{\mathrm{ij}} \times \mathrm{P}_{\mathrm{Y} . \mathrm{Xi}} \times \mathrm{P}_{\mathrm{Y} . \mathrm{Xj}}
\end{gathered}
$$

(Equation 3)

(Equation 4)

where $d_{i}$ is the effect of a single trait $\mathrm{X}_{\mathrm{i}}$ on $\mathrm{Y} ; P_{Y X i}$ is the path coefficient from $\mathrm{X}_{\mathrm{i}}$ to $\mathrm{Y} ; d_{i j}$ is the effect of traits $\mathrm{X}_{\mathrm{i}}$ and $\mathrm{X}_{\mathrm{j}}$ on $\mathrm{Y}$; $r_{i j}$ is the correlation coefficient between traits $\mathrm{i}$ and $\mathrm{j}$; and $P_{Y . X j}$ is the path coefficient from trait $X_{j}$ to $Y$.

\section{RESULTS}

\section{Descriptive statistics of morphological traits}

The mean, SD, and CV for the 20 morphometric traits and body weight of $L$. maculatus are presented in Table 1 . In the case of the morphometric traits, the CV for $\mathrm{X}_{18}(23.73 \%), \mathrm{X}_{16}$ $(19.59 \%)$, and $\mathrm{X}_{17}(18.24 \%)$ were the highest, whereas $\mathrm{X}_{1}$ and $\mathrm{X}_{19}$ had the lowest $\mathrm{CV}(10.24 \%)$. The CV for body weight was $35.25 \%$, which was higher than any of the morphometric traits.

\begin{tabular}{|c|c|c|c|c|c|c|}
\hline Trait name & Abbreviation & Minimum & Maximum & Mean & SD & $\mathrm{CV}(\%)$ \\
\hline Total length & $\mathrm{X}_{1}$ & 225.55 & 360.02 & 289.23 & 29.62 & 10.24 \\
\hline Body length & $\mathrm{X}_{2}$ & 185.68 & 285.01 & 242.66 & 25.06 & 10.33 \\
\hline Distance from the tip of lower jaw to anus & $\mathrm{X}_{3}$ & 127.00 & 216.87 & 159.28 & 16.88 & 10.60 \\
\hline Body height & $\mathrm{X}_{4}$ & 48.81 & 87.65 & 65.96 & 8.10 & 12.29 \\
\hline Body width & $\mathrm{X}_{5}$ & 23.14 & 43.19 & 32.32 & 5.25 & 16.24 \\
\hline Caudal peduncle height & $X_{6}$ & 18.00 & 33.92 & 23.59 & 3.72 & 15.77 \\
\hline Caudal peduncle length & $\mathrm{X}_{7}$ & 30.29 & 61.00 & 46.72 & 6.42 & 13.74 \\
\hline Distance from snout tip to first dorsal fin origin & $\mathrm{X}_{8}$ & 46.08 & 101.06 & 80.26 & 9.71 & 12.10 \\
\hline Basal length of dorsal fin & $\mathrm{X}_{9}$ & 11.07 & 153.56 & 114.17 & 18.05 & 15.81 \\
\hline Distance from first dorsal fin origin to anal fin origin & $\mathrm{X}_{10}$ & 84.72 & 134.34 & 110.45 & 11.99 & 10.86 \\
\hline Distance from the tip of lower jaw to pelvic fin origin & $\mathrm{X}_{11}$ & 68.54 & 105.31 & 86.41 & 9.64 & 11.15 \\
\hline Basal length of anal fin & $\mathrm{X}_{12}$ & 20.24 & 37.99 & 28.58 & 4.03 & 14.10 \\
\hline Pectoral fin length & $\mathrm{X}_{13}$ & 25.00 & 56.76 & 40.52 & 6.50 & 16.04 \\
\hline Pelvic fin length & $\mathrm{X}_{14}$ & 30.00 & 55.05 & 42.88 & 5.42 & 12.64 \\
\hline Head length & $\mathrm{X}_{15}$ & 61.00 & 95.44 & 76.05 & 8.11 & 10.67 \\
\hline Snout length & $\mathrm{X}_{16}$ & 12.16 & 27.55 & 16.69 & 3.27 & 19.59 \\
\hline Eye diameter & $\mathrm{X}_{17}$ & 12.01 & 25.24 & 15.58 & 2.84 & 18.24 \\
\hline Eye cross & $\mathrm{X}_{18}$ & 10.04 & 24.88 & 13.99 & 3.32 & 23.73 \\
\hline Slanting distance from snout tip to first dorsal fin origin & $\mathrm{X}_{19}$ & 69.76 & 104.51 & 86.39 & 8.85 & 10.24 \\
\hline Distance from the tip of lower jaw to top of pectoral fin origin & $\mathrm{X}_{20}$ & 59.21 & 92.56 & 74.47 & 8.00 & 10.74 \\
\hline Body weight & $\mathrm{Y}$ & 111.50 & 442.30 & 255.88 & 90.20 & 35.25 \\
\hline
\end{tabular}

Table 1. Descriptive statistics of morphological traits and body weight of Lateolabrax maculatus $(\mathrm{N}=87)$.

For each trait, the name, abbreviation, minimum, maximum, mean, standard deviation (SD), and coefficient of variation $(\mathrm{CV}, \%)$ are given. All measurements are reported in $\mathrm{mm}$, except body weight which is reported in $\mathrm{g}$.

\section{Correlation coefficients among the morphological traits}

The correlation coefficients among the 21 morphological traits (including the 20 morphometric traits and body weight) of L. maculatus are presented in Table 2. Significant correlations were detected in all comparisons among all measured traits. The highest correlation coefficient was found in the correlation between $X_{1}$ and $X_{2}$, with a value of 0.974 , followed by the correlations between $X_{2}$ and $X_{10}(0.957)$ and $X_{11}$ and $X_{20}$ (0.955). All 20 morphometric traits were found to correlate significantly with body weight, with the correlation coefficient ranging from 0.193 (between $\mathrm{Y}$ and $\mathrm{X}_{18}$ ) to 0.933 (between $\mathrm{Y}$ and $\mathrm{X}_{1}$ ).

Genetics and Molecular Research 15 (3): gmr.15038285 
W. Wang et al.

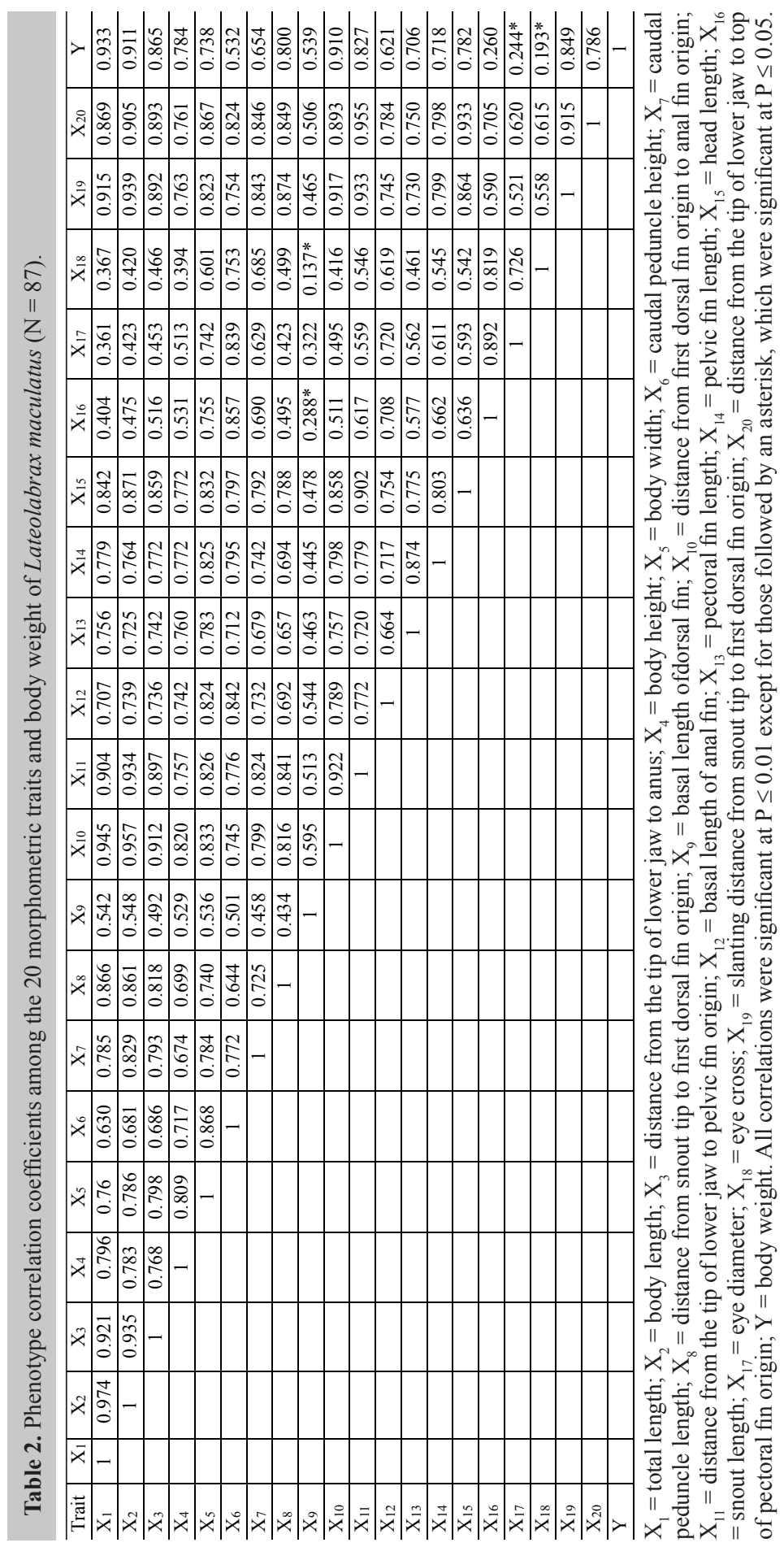

Genetics and Molecular Research 15 (3): gmr.15038285 


\section{Path and determination coefficients}

The direct and indirect effects of the different morphometric traits on body weight were evaluated using path correlation analysis. Of the 20 morphometric traits, seven traits $\left(\mathrm{X}_{1}, \mathrm{X}_{5}, \mathrm{X}_{10}, \mathrm{X}_{16}, \mathrm{X}_{17}, \mathrm{X}_{18}\right.$, and $\left.\mathrm{X}_{19}\right)$ showed significant direct effects on body weight (Table 3 ). The direct effects of these traits on body weight ranged from $-0.123\left(\mathrm{X}_{18}\right)$ to $0.450\left(\mathrm{X}_{5}\right)$. Only the direct effect of $\mathrm{X}_{5}$ was greater than the indirect effects on body weight. $\mathrm{X}_{10}$ had the largest indirect effect $(0.331)$ on body weight through $\mathrm{X}_{5}$.

Table 3. Direct and indirect effects of morphometric traits on body weight of Lateolabrax maculatus $(\mathrm{N}=87)$.

\begin{tabular}{l|c|c|c|c|c|c|c|c|c|c}
\hline Trait $\left(\mathrm{X}_{\mathrm{i}}\right)$ & Related coefficient & \multirow{2}{*}{ Direct effect } & \multicolumn{9}{|c|}{ Indirect effect $\left(\mathrm{X}_{\mathrm{j}}\right)$} \\
\cline { 4 - 11 } & & & $\sum$ & $\mathrm{X}_{1}$ & $\mathrm{X}_{5}$ & $\mathrm{X}_{10}$ & $\mathrm{X}_{16}$ & $\mathrm{X}_{17}$ & $\mathrm{X}_{18}$ & $\mathrm{X}_{19}$ \\
\hline $\mathrm{X}_{1}$ & 0.933 & 0.350 & 0.583 & & 0.342 & 0.248 & -0.103 & -0.050 & -0.045 & 0.192 \\
\hline $\mathrm{X}_{5}$ & 0.737 & 0.450 & 0.288 & 0.266 & & 0.218 & -0.193 & -0.103 & -0.074 & 0.173 \\
\hline $\mathrm{X}_{10}$ & 0.910 & 0.262 & 0.648 & 0.331 & 0.375 & & -0.130 & -0.069 & -0.051 & 0.193 \\
\hline $\mathrm{X}_{16}$ & 0.259 & -0.255 & 0.514 & 0.141 & 0.340 & 0.134 & & -0.124 & -0.101 & 0.124 \\
\hline $\mathrm{X}_{17}$ & 0.244 & -0.139 & 0.383 & 0.126 & 0.334 & 0.130 & -0.227 & & -0.089 & 0.109 \\
\hline $\mathrm{X}_{18}$ & 0.192 & -0.123 & 0.315 & 0.128 & 0.270 & 0.109 & -0.209 & -0.101 & & 0.117 \\
\hline $\mathrm{X}_{19}$ & 0.849 & 0.210 & 0.639 & 0.320 & 0.370 & 0.240 & -0.150 & -0.072 & -0.069 & \\
\hline
\end{tabular}

The indirect effect of $X_{\mathrm{i}} \mathrm{X}_{\mathrm{j}}$ means the indirect effect of $\mathrm{X}_{\mathrm{i}}$ on body weight through $\mathrm{X}_{\mathrm{j}}$. $\sum$ means the total indirect effects of $X_{i}$ on body weight. In this table, $X_{1}=$ total length; $X_{5}=$ body width; $X_{10}=$ distance from first dorsal fin origin to anal fin origin; $\mathrm{X}_{16}=$ snout length; $\mathrm{X}_{17}=$ eye diameter; $\mathrm{X}_{18}=$ eye cross; $\mathrm{X}_{19}=$ slanting distance from snout tip to first dorsal fin origin.

The determination coefficients of the morphometric traits on body weigh are listed in Table 4. The determination coefficient of $X_{5}$ was the largest (0.203), whereas that of $X_{18}$ was the lowest (0.015). The co-determinant coefficient of $X_{1}$ and $X_{5}$ on body weight was found to be the highest, with a value of 0.239 . The sum of the determination coefficients $\mathrm{X}_{1}, \mathrm{X}_{5}, \mathrm{X}_{10}$, $\mathrm{X}_{16}, \mathrm{X}_{17}, \mathrm{X}_{18}$, and $\mathrm{X}_{19}$ on body weight was 0.953 , indicating that these seven traits significantly affect the body weight of $L$. maculatus.

Table 4. Determinant coefficients of morphometric traits on body weight of Lateolabrax maculatus $(\mathrm{N}=87)$.

\begin{tabular}{l|c|c|c|c|c|c|c}
\hline Trait & \multicolumn{7}{|c|}{$\mathrm{X}_{\mathrm{j}}$} \\
\hline $\mathrm{X}_{\mathrm{i}}$ & $\mathrm{X}_{1}$ & $\mathrm{X}_{5}$ & $\mathrm{X}_{10}$ & $\mathrm{X}_{16}$ & $\mathrm{X}_{17}$ & $\mathrm{X}_{18}$ & $\mathrm{X}_{19}$ \\
\hline $\mathrm{X}_{1}$ & $\mathbf{0 . 1 2 3}$ & 0.239 & 0.173 & -0.072 & -0.035 & -0.032 & 0.135 \\
\hline $\mathrm{X}_{5}$ & & $\mathbf{0 . 2 0 3}$ & 0.196 & -0.173 & -0.093 & -0.067 & 0.156 \\
\hline $\mathrm{X}_{10}$ & & & $\mathbf{0 . 0 6 9}$ & -0.068 & -0.036 & -0.027 & 0.101 \\
\hline $\mathrm{X}_{16}$ & & & $\mathbf{0 . 0 6 5}$ & 0.063 & 0.051 & -0.063 \\
\hline $\mathrm{X}_{17}$ & & & & $\mathbf{0 . 0 1 9}$ & 0.025 & -0.030 \\
\hline $\mathrm{X}_{18}$ & & & & & & $\mathbf{0 . 0 1 5}$ & -0.029 \\
\hline $\mathrm{X}_{19}$ & & & & & & & $\mathbf{0 . 0 4 4}$ \\
\hline
\end{tabular}

The co-determinant $\left(\mathrm{d}_{\mathrm{ij}}\right)$ and determination $\left(\mathrm{d}_{\mathrm{i}}\right)$ coefficients are shown on the off-diagonal and the diagonal (highlighted in bold), respectively. $d_{i}$ is the effect of a single trait $X_{i}$ on body weight and $d_{i j}$ is the effect of traits $X_{i}$ and $X_{j}$ on body weight. $X_{1}=$ total length; $X_{5}=$ body width; $X_{10}=$ distance from first dorsal fin origin to anal fin origin; $X_{16}=$ snout length; $\mathrm{X}_{17}=$ eye diameter; $\mathrm{X}_{18}=$ eye cross; $\mathrm{X}_{19}=$ slanting distance from snout tip to first dorsal fin origin.

\section{Construction of multiple-regression equation}

The regression relationship between the morphometric traits and body weight of $L$. maculatus was estimated using a stepwise multiple-regression analysis, which can be used to identify the significance of partial regression coefficients by gradually removing non-

Genetics and Molecular Research 15 (3): gmr.15038285 
significant parameters (Zhao et al., 2014). We found that the same seven traits as identified above $\left(\mathrm{X}_{1}, \mathrm{X}_{5}, \mathrm{X}_{10}, \mathrm{X}_{16}, \mathrm{X}_{17}, \mathrm{X}_{18}\right.$, and $\left.\mathrm{X}_{19}\right)$ showed significant relationships with body weight. The best-fit multiple-regression equation of body weight was: $\mathrm{Y}=-472.108+1.065 \mathrm{X}_{1}+$ $7.728 \mathrm{X}_{5}+1.973 \mathrm{X}_{10}-7.024 \mathrm{X}_{16}-4.400 \mathrm{X}_{17}-3.338 \mathrm{X}_{18}+2.138 \mathrm{X}_{19}$. The results of the analysis of variance on the multiple-regression equation are shown in Table 5 . The $\mathrm{P}$ value of this equation was $<0.01$, indicating that the prediction of body weight, in relation to these morphometric traits, is reliable (Zhao et al., 2014). The adjusted multiple-correlation coefficient was 0.947 , indicating that the above mentioned seven morphometric traits can be considered key factors affecting the body weight of $L$. maculatus. This is consistent with the results found for the determination coefficients.

Table 5. Analysis of variance of multiple-regression equation of Lateolabrax maculatus $(\mathrm{N}=87)$.

\begin{tabular}{l|c|c|c|c|c}
\hline Index & Sum of squares & d.f. & Mean square & F & P \\
\hline Regression analysis & $66,5501.369$ & 7 & 95071.624 & 219.378 & $<0.001$ \\
\hline Residual & $34,236.169$ & 79 & 433.369 & & \\
\hline Total & $699,737.537$ & 86 & & & \\
\hline
\end{tabular}

The adjusted multiple-correlation coefficient of this equation is 0.947 .

\section{DISCUSSION}

Enhancing production is one of the main objectives in aquaculture. Therefore, body weight is often considered an important indicator for direct selection that is used in many aquaculture-breeding programs. However, due to the effects of genetic linkage, pleiotropy and environmental factors (Toro and Newkirk, 1990; Li et al., 2006; Fu et al., 2015), it has proven difficult to achieve satisfactory results in the selection programs when only taking body weight into account. However, body weight has been found to be highly correlated with many other morphological traits (Pérez-Rostro and Ibarra, 2003). In the present study, abundant variation was found in the 21 morphological traits of $L$. maculatus. A high $\mathrm{CV}$ was found for traits $\mathrm{X}_{18}$ (23.73\%), $X_{16}(19.59 \%)$, and $X_{17}(18.24 \%)$, whereas $X_{1}$ and $X_{19}$ had the lowest CV (10.24\%). This high variation in morphological traits, which was consistent with the previously determined genetic diversity of L. maculatus (Shao et al., 2009; An et al., 2013, 2014; Han et al., 2015), could provide sufficient materials for economic performance selection in this species.

A correlation analysis indicated that all 20 morphometric traits were significantly correlated with body weight. Furthermore, the correlation coefficients of $X_{1}, X_{2}, X_{3}$, and $\mathrm{X}_{10}$ with body weight were all higher than 0.85 . However, it has been well established that only using correlation coefficients between morphometric traits and body weight might not adequately explain all aspects of their relationships and an investigation of the causality of these relationships is necessary (Falconer and Mackay, 1996). To this end, we used a path analysis to estimate the contribution of each morphometric trait on body weight and to identify economically important traits for selective purposes. Our results revealed that, although the correlation coefficients of 13 morphometric traits $\left(\mathrm{X}_{2}, \mathrm{X}_{3}, \mathrm{X}_{4}, \mathrm{X}_{6}, \mathrm{X}_{7}, \mathrm{X}_{8}, \mathrm{X}_{9}\right.$, $\mathrm{X}_{11}, \mathrm{X}_{12}, \mathrm{X}_{13}, \mathrm{X}_{14}, \mathrm{X}_{15}$, and $\mathrm{X}_{20}$ ) on body weight were highly significant, their respective direct effects on body weight were not significant. Thus, these traits were sequentially deleted from a multiple-regression analysis of body weight. The remaining seven morphometric traits were used to construct a simplified multiple-regression equation: $\mathrm{Y}=-472.108+1.06 \mathrm{X}_{1}$ $+7.728 \mathrm{X}_{5}+1.973 \mathrm{X}_{10}-7.024 \mathrm{X}_{16}-4.400 \mathrm{X}_{17}-3.338 \mathrm{X}_{18}+2.138 \mathrm{X}_{19}$. The adjusted multiple- 
correlation coefficient of this equation was 0.947 , which suggested that these traits $\left(\mathrm{X}_{1}, \mathrm{X}_{5}\right.$, $\mathrm{X}_{10}, \mathrm{X}_{16}, \mathrm{X}_{17}, \mathrm{X}_{18}$, and $\mathrm{X}_{19}$ ) could be considered main factors affecting the body weight of L. maculatus. This result is similar to those found in previous studies in other fish species (Zhang et al., 2008; Tong et al., 2007, 2011; Wang et al., 2014). By using path analysis, total length has been identified as a key factor that had the largest direct effect on body weight in Hucho taimen (Tong et al., 2011), Pelteobagrus fulvidraco (Wang et al., 2014), as well as in $\mathrm{F}_{1}$ hybrids of Cyprinus carpio L. and Cyprinus carpio haematopterus (Tong et al., 2007). In Ctenopharyngodon idella, the traits with the strongest direct and indirect effects on body weight were body length and body width, respectively (Sun et al., 2015). These differences may in part be derived from the different body types of these species. In the present study, body width $\left(\mathrm{X}_{5}\right)$ had the highest positive direct correlation with body weight, whereas total length $\left(\mathrm{X}_{1}\right)$ mainly had an indirect effect. These results were similar to those found by $\mathrm{He}$ et al. (2009) in Micropterus salmoides, which is closely related to L. maculatus. It is worth noting that only the direct effect of $\mathrm{X}_{5}$ was greater than any of the indirect effects on body weight. At the same time, high indirect effects on body weight of $\mathrm{X}_{1}, \mathrm{X}_{10}, \mathrm{X}_{16}, \mathrm{X}_{17}, \mathrm{X}_{18}$, and $\mathrm{X}_{19}$ through $\mathrm{X}_{5}$ were identified in this study. Hence, $\mathrm{X}_{5}$ could be considered the most important morphometric trait, as indicated by the identified significant effects on L. maculatus body weight. In a previous study on Sparusaurata, broodstocks divided into two groups based on larval body width were analyzed to evaluate growth and carcass traits (Mazzeo et al., 2014). Their results showed that the specimens that had the largest body widths reached the largest sizes and performed better both in terms of general well-being and degree of nourishment. In combination with the findings from our own study, body width could be used as an effective morphometric indicator in breeding programs of L. maculatus.

In conclusion, the identified correlations among the 20 morphometric traits and body weight of L. maculatus were further tested using path and regression analyses in this study. Using these methods, seven morphometric traits $\left(\mathrm{X}_{1}, \mathrm{X}_{5}, \mathrm{X}_{10}, \mathrm{X}_{16}, \mathrm{X}_{17}, \mathrm{X}_{18}\right.$, and $\left.\mathrm{X}_{19}\right)$ were identified as having significant effects on body weight. A best-fit multiple-regression equation was constructed relating these seven morphometric traits to body weight. Body width was identified as a key trait affecting L. maculatus body weight. This knowledge will provide useful and valuable information for promoting the breeding programs of L. maculatus by identifying traits related to body weight and other important economic properties. It is worth mentioning that, due to the long sexual maturation cycle of this species, the gender of the fish was not considered in this study. Likewise, the genetic background of the identified correlations among the morphological traits was not discussed. These aspects should be highlighted in future studies.

\section{Conflicts of interest}

The authors declare no conflict of interest.

\section{ACKNOWLEDGMENTS}

We thank Dr. Chao Song, Dr. Anglv Shen, Captain Yuzhong Chen, and Captain Yanghua Tang for assistance in the collection of the samples. We also thank Fenfang Chen, Ming Zhao, and Mengdi Zhao for their assistance in the measurement of the morphological traits. Research supported by the National Non-Profit Institutes (East China Sea Fisheries Research Institute;

Genetics and Molecular Research 15 (3): gmr.15038285 
\#2015M03), the National Science \& Technology Support Plan (\#2013BAD13B05), and the National Basic Research Special Foundation of China (\#2013FY110700).

\section{REFERENCES}

An HS, Lee JW, Kim HY, Kim JB, et al. (2013). Genetic differences between wild and hatchery populations of Korean spotted sea bass (Lateolabrax maculatus) inferred from microsatellite markers. Genes Genomics 35: 671-680. http:// dx.doi.org/10.1007/s13258-013-0135-z

An HS, Kim HY, Kim JB, Chang DS, et al. (2014). Genetic characterization of hatchery populations of Korean spotted sea bass (Lateolabrax maculatus) using multiplex polymerase chain reaction assays. Genet. Mol. Res. 13: 6701-6715. http://dx.doi.org/10.4238/2014.August.28.14

Borrell YJ, Carleos CE, Asturiano JF, Bernardo D, et al. (2007). Use of microsatellites and a combinatorial optimization approach in the acquisition of gilthead seabream (Sparus aurata L.) broodstocks for hatcheries. Aquaculture 269: 200-210. http://dx.doi.org/10.1016/j.aquaculture.2007.04.055

Du JJ and Chen ZW (2010). Carrying out path analysis by linear regression of SPSS. Bol. Biol. 45: 4-6.

Falconer DS and Mackay TFC (1996). Introduction to quantitative genetics. 4th edn. LongmansGreen, Harlow, Essex.

Fu JJ, Shen YB, Xu XY, Liu CC, et al. (2015). Genetic parameter estimates and genotype by environment interaction analyses for early growth traits in grass carp (Ctenopharyngodon idella). Aquacult. Int. 23: 1427-1441. http://dx.doi. org/10.1007/s10499-015-9894-7

Haffray P, Vandeputte M, Petit V, Pincent C, et al. (2012). Minimizing maternal effect in salmonid families mixed since eyed stages and a posteriori DNA-pedigreed. Livest. Sci. 150: 170-178. http://dx.doi.org/10.1016/j.livsci.2012.08.017

Han ZQ, Han G, Wang ZY, Sui BN, et al. (2015). The genetic divergence and genetic structure of two closely related fish species Lateolabrax maculatus and Lateolabrax japonicus in the Northwestern Pacific inferred from AFLP markers. Genes Genomics 37: 471-477. http://dx.doi.org/10.1007/s13258-015-0276-3

Harrison TD (2001). Length-weight relationships of fishes from South African estuaries. J. Appl. Ichthyology 17: 46-48. http://dx.doi.org/10.1046/j.1439-0426.2001.00277.x

He XY, Liu XL, Bai JJ, Li SJ, et al. (2009). Mathematical analysis of effects of morphometric attribute on body weight of largemouth bass (Micropterus salmoides). J. Fish. China 33: 597-603.

Kause A, Ritola O, Paananen T, Mäntysaaria E, et al. (2002). Coupling body weight and its composition: a quantitative genetic analysis in rainbow trout. Aquaculture 211: 65-79. http://dx.doi.org/10.1016/S0044-8486(01)00884-5

Kim YU, Myoung JG, Kim YS, Han KH, et al. (2001).The marine fishes of Korea. Hanguel Publishing Co., Busan, 22.

Lee WK and Yang SW (2002). Relationship between ovarian development and serum levels of gonadal steroid hormones, and induction of oocyte maturation and ovulation in the cultured female Korean spotted sea bass Lateolabrax maculatus (Jeom-nong-eo). Aquaculture 39: 169-183. http://dx.doi.org/10.1016/S0044-8486(01)00728-1

Li SF, Wang CH, Liu ZG, Xiang SP, et al. (2006). Analysis of heterosis and genetic correlation of growth traits in three variants of red common carp. J. Fish. China 30: 175-180.

Li Y, Ai QH, Mai KS, Xu W, et al. (2012). Effects of the partial substitution of dietary fish meal by two types of soybean meals on the growth performance of juvenile Japanese seabass, Lateolabrax japonicus (Cuvier 1828). Aquacult. Res. 43: 458-466. http://dx.doi.org/10.1111/j.1365-2109.2011.02849.x

Liu CL, Chang YM, Liang LQ, Xu LH, et al. (2011). Correlation and path analyses of phenotypic traits and body mass of transgenic carp with growth hormone gene of salmon. Ying Yong Sheng Tai Xue Bao 22: 1893-1899.

Liu JX, Gao TX, Yokogawa K and Zhang YP (2006). Differential population structuring and demographic history of two closely related fish species, Japanese sea bass (Lateolabrax japonicus) and spotted sea bass (Lateolabrax maculatus) in Northwestern Pacific. Mol. Phylogenet. Evol. 39: 799-811.http://dx.doi.org/10.1016/j.ympev.2006.01.009

Ma HY, Ma CY, Ma LB, Xu Z, et al. (2013). Correlation of growth-related traits and their effects on body weight of the mud crab (Scylla paramamosain). Genet. Mol. Res. 12: 4127-4136. http://dx.doi.org/10.4238/2013.October.1.3

Mazzeo I, Borrell YJ, Gallego V, García Fernández C, et al. (2014). Larval width as indicator of growth rate and effect of larval classification on final body composition and flesh quality in cultured gilthead seabream (Sparus aurata, L.). $J$. Appl. Ichthyology 30: 300-306. http://dx.doi.org/10.1111/jai.12380

Pérez-Rostro CI and Ibarra AM (2003). Quantitative genetic parameter estimates for size and growth rate traits in Pacific white shrimp, Penaeus vannamei (Boone 1931) when reared indoors. Aquacult. Res. 34: 543-553. http://dx.doi. org/10.1046/j.1365-2109.2003.00851.x

Ruiz-Campos G, Camarena-Rosales F, Varela-Romero A, Sánchez-Gonzáles S, et al. (2003). Morphometric variation of wild trout populations from northwestern Mexico (Pisces: Salmonidae). Rev. Fish Biol. Fish. 13: 91-110. http:// dx.doi.org/10.1023/A:1026367113735

Genetics and Molecular Research 15 (3): gmr.15038285 
Sang NV, Thomassen M, Klemetsdal G and Gjøen HM (2009). Prediction of fillet weight, fillet yield, and fillet fat for live river catfish (Pangasianodon hypophthalmus). Aquaculture 288: 166-171. http://dx.doi.org/10.1016/j. aquaculture.2008.11.030

Shao CW, Chen SL, Xu GB, Liao XL, et al. (2009). Eighteen novel microsatellite markers for the Chinese sea perch, Lateolabrax maculatus. Conserv. Genet. 10: 623-625. http://dx.doi.org/10.1007/s10592-008-9592-3

Sun JL, Shen YB, Fu JJ, Yu HY, et al. (2015). The effects of the morphometric traits at different month ages on body weight of Ctenopharyngodon idellus. J. Shanghai Ocean Univ. 24: 341-349.

Tian YS, Xu TJ, Liang Y and Chen SL (2011). Estimates of genetic and phenotypic parameters for weight and length in Paralichthys olivaceus (Temminck et Schlegel). Acta Oceanol. Sin. 30: 58-64. http://dx.doi.org/10.1007/s13131$\underline{011-0161-0}$

Tong GX, Kuang YY, Xu LX, Liu B, et al. (2011). Mathematical analysis of effects of morphometric attributes on body weight in Taimen Hucho taimen. Chin. J. Fish. 24: 31-36.

Tong XH, Dong ZJ, Miao WM, Yuan XH, et al. (2007). The heterosis of $\mathrm{F}_{1}$ hybrids (jian carp $\mathrm{x}$ huanghe carp) and path analysis of main growth traits. J. Dalian Fish. Univ. 22: 159-163.

Toro JE and Newkirk GF (1990). Divergent selection for growth rate in the European oyster Ostreaedulis: response to selection and estimate of genetic parameters. Mar. Ecol. Prog. Ser. 62: 219-227. http://dx.doi.org/10.3354/ meps062219

Trong TQ, Mulder HA, van Arendonk JAM and Komen H (2013). Heritability and genotype by environment interaction estimates for harvest weight, growth rate, and shape of Nile tilapia (Oreochromis niloticus) grown in river cage and VAC in Vietnam. Aquaculture 384-387: 119-127. http://dx.doi.org/10.1016/j.aquaculture.2012.12.022

Wada H (1986). Computers and prime factor analysis. Sügaku 38: 345-350.

Wang J, Ai QH, Mai KS, Xu HG, et al. (2015a). Effects of dietary ethoxyquin on growth, feed utilization and residue in the muscle of juvenile Japanese seabass, Lateolabrax japonicas. Aquacult. Res. 46: 2656-2664. http://dx.doi. org/10.1111/are. 12420

Wang MH, Zhong LQ, Cai YX, Chen YM, et al. (2014). Analysis of effects of morphometric traits on body weight of yellow catfish Pelteobagrus fulvidraco. J Zhejiang Ocean Univ. (Nat. Sci.) 33: 41-46.

Wang XA, Ma AJ, Huang ZH and Zhou Z (2010). Heritability and genetic correlation of survival in turbot (Scophthalmus maximus). Chin. J. Oceanology Limnol. 28: 1200-1205. http://dx.doi.org/10.1007/s00343-010-9014-5

Wang Y, Wang F, Ji WX, Han H, et al. (2015b). Optimizing dietary protein sources for Japanese seabass (Lateolabrax japonicus) with an emphasis on using poultry by-product meal to substitute fish meal. Aquacult. Res. 46: 874-883. http://dx.doi.org/10.1111/are.12242

Yokogawa K and Seki S (1995). Morphological and genetic differences between Japanese and Chinese sea bass of the genus Lateolabrax. Jpn. J. Ichthyol. 41: 437-445.

Yuan MY, Liu SF, Wang ZC, Li DP, et al. (2012). Effects of morphometric traits on body weight for juvenile Polyodon spathuln. J. Anhui Agric. Univ. 39: 201-206.

Zhang QW, Zhang TY, Kong J and Luan S (2008). Correlation of growth traits of turbot Scophthalmus maximus at different developmental stages. Progr. Fish. Sci. 29: 57-61.

Zhao LQ, He YY, Yang F, Nie HT, et al. (2014). Correlation and path analysis of morphological and weight traits in marine gastropod Glossaulax reiniana. Chin. J. Oceanology Limnol. 32: 821-827. http://dx.doi.org/10.1007/s00343014-3290-4

Genetics and Molecular Research 15 (3): gmr.15038285 